\title{
The Sound of Danger: Voice, Noise and Risk in Building Material Production in Early Twentieth- Century Palestine
}

\author{
Nimrod Ben Zeev
}

HCM 7: 492-503

DOI: $10.18352 / \mathrm{hcm} .566$

\begin{abstract}
This article offers an analysis of the vernacular auditory cultures of safety and risk in construction material production in early twentiethcentury Palestine. It examines the qualitatively different understandings and uses of sounds, from workers' singing to heavy machinery, which characterized dangerous work in Palestine's rural limekilns and its then sole industrial cement factory. The article suggests that in order to understand the 'sound of modernity,' we need to expand the geographic and thematic scope of our studies: looking beyond those for which sound became obsession or profession and the cultural sensibilities of elites, and incorporating the ways in which indigenous and colonial working classes in the colonized world made sense and use of the auditory.
\end{abstract}

Keywords: body, labour, Middle East, Palestine, sound

\section{Introduction}

Where do we begin looking for the sounds of modernity? And what do we expect to learn from uncovering these sonic histories? For most historical sound studies published in recent years, the sounds of modernity have been bound with nineteenth and twentieth-century processes of urbanization in Europe and North America. These studies have 
focused on rapidly changing environments and scientific knowledge amidst burgeoning urban populations, the growth of modern industry, new consumer goods and patterns of consumption, and the rise of often self-described 'modern' arts and culture. Their titles often capture the dynamism and the sheer volumes they seek to describe: The Feel of the City; City of Noise; Sensing Chicago; The Age of Noise in Britain. ${ }^{1}$

This brief essay shifts our attention from the sounds of European and North American cities to a different geography, the outskirts of colonial cities. It focuses not on the sounds perceived by the social, cultural, and scientific discourses that described and constituted modern urbanism, but on the manufacturing processes of building materials which literally made up the urban built environment. The essay explores the partial transition of the building materials industry in early twentieth-century Palestine, from rural limekilns and stone structures, to mass-manufactured and imported Portland cement and the concrete it was used to produce. It follows works that foreground the safety and health risks of industrial noise on the one hand, and new approaches to cultures of singing at work on the other. In light of these, the essay reveals not only changes in the auditory as work safety problem, but also in how sound was used and understood in 'vernacular' cultures of safety and risk as part of the labour process. In other words, how dangerous work sounded. ${ }^{2}$ At the same time, this essay suggests we look beyond approaches to the history of sound (and the senses more broadly) that privilege those for which sound or noise became obsession or profession, or the cultural sensibilities of Western elites. Rather, it is imperative we try and find ways to hear a more popular history of sound, related to differently classed, raced, and gendered bodily experiences, across different geographies.

\section{The Limekiln and the Cement Factory}

The period of British rule over Palestine, between I9I7 and I948, was a period of immense political, social, economic and technological changes. While these changes certainly did not come out of nowhere many of them had their roots in the final decades of Ottoman rule the pace of change during the British Mandate was often furious. Dramatic shifts were driven by the incorporation of Palestine into a rapidly changing imperial formation, unprecedented waves of internal 
and external migration, large capital flows into the territory and world historical events. ${ }^{3}$

One area in which such shifts were felt was Palestine's built environment. In line with the massive waves of immigration and internal migration, construction played a disproportionate role in Palestine's economy during the Mandate. The building materials industry also witnessed upheavals. Portland cement, a hydraulic cement patented in England in the early nineteenth century and produced by the fusing of limestone and aluminosilicates, was first imported into Palestine in the I 89os. Cement introduced unprecedented advantages to the building sector, allowing to erect cheap and durable buildings at rapid pace. It was for this reason that, in the initial decades of the twentieth century, amidst several initiatives and calls for broader use of cement in the land, some Zionist entrepreneurs sought in the grey substance a replacement for Palestinian stone and lime-based mortars, one that would grant a decisive advantage to Jewish labourers. ${ }^{4}$ In the first years of the war's aftermath the volume of imported cement steadily increased. Then in I923 the Russian-born Jewish industrialist Michael Pollak established the Nesher Portland Cement Company. The company selected a plot of land outside the city of Haifa, which would soon become Palestine's main port and a key British imperial hub. Nesher then set upon building what was to become Palestine's single largest industrial plant and its sole producer of cement. ${ }^{5}$

Prior to the wide-scale adoption of Portland cement and concrete during the I920s, rural limekilns (Arabic: al-latun) were the primary producers of mortar and plaster for Palestine's stone-built architecture, which was characteristic of its coastal towns and the hilly areas of its interior. ${ }^{6}$ Several forms of kilns were in use in the first half of the twentieth century. The earliest and most basic were stone-built structures fuelled by brushwood. Diesel, crude oil and coal-fuelled kilns capable of industrial-levels of output and intended for commercial production, first came into use in the late I920s. While Portland cement (Arabic: asmant or shimento, Hebrew: melet) did eventually become the dominant mortar and concrete increasingly displaced stone, various forms of kilns, big and small, continued to operate throughout the period of British rule. ${ }^{7}$

When the Nesher Portland Cement Company began operations in I925 it quickly established itself as a monopoly in the Palestinian market. This was partly a result of the factory's pioneering status, but also 
of Michael Pollak's keen business and imperial acumen. Within the factory itself, only Jewish workers were employed. In the adjacent quarry which supplied the factory with raw material, however, work was carried out only by Palestinian Arabs. The latter were not employed by the factory directly, but by a Palestinian contractor Pollak had hired. Only in I936, as a result of a six-month long Palestinian Arab general strike and the anti-colonial revolt that ensued, was the Solel Boneh contracting company (an organ of the Zionist General Federation of Trade Unions, the Histadrut) able to convince Pollak to introduce Jewish workers to the quarry as well. ${ }^{8}$ Meanwhile, while some limekilns were owned and operated by Jews, the majority of kiln and quarry workers throughout Palestine remained Palestinian Arabs. The limekiln and the cement factory were thus separated not only by ownership patterns and technical processes, but also by the identities of those who worked in them. In what follows, we shall see also how dangerous work in both production facilities was granted aural presence in different ways.

\section{'Stone Cuisine': Singing between the Flames}

Descriptions of the industrial sounds of the Nesher cement factory in its initial decades of operation, which I will return to below, can be found in the contemporary Hebrew press. The sounds of the limekilns, however, seem to have left considerably less historical traces. What we do have at our disposal, is a body of songs authored and sung by Palestinian Arab limekiln workers and 'collected' by scholars of Palestinian folklore. 9 The question then becomes, how do we move from the texts of songs, the aural qualities of which we have very little information about, to a sound study?

Palestinian studies of local singing practices offer an interpretative approach to singing at work which is particularly useful in this regard and that seems in retrospect ahead of its time. In particular, 'Ali al-Khalili's I979 study, Aghani al- 'Amal wa-l- 'Umal (Songs of Labour and Labourers), approaches singing at work in a manner which seems to anticipate that of Korczynski, Pickering, and Robertson's considerably more recent Rhythms of Labour. Like the authors of Rhythms of Labour, al-Khalili emphasizes singing at work's role in 'passing time' rather than 'keeping time', singing's aesthetic dimensions, the poetics and meanings of songs' lyrics, the role of singing in ameliorating 
difficult, painful and tedious work, and its occasional use as a form of protest. ${ }^{\text {Io }}$ Thus, both Aghani al-'Amal wa-l-'Umal and Rhythms of Labour call attention to the performative, embodied aspects of singing at work and its purposes for workers rather than for the work they carried out. This approach allows us to think of singing at work as a material, acoustic and aural phenomenon, even in the absence of descriptions of how the songs sounded.

Neither of the studies dwells on the ways in which singing functioned in the face of dangerous work in particular. ${ }^{11}$ However, the song which is at the centre of this section, Ya Badal Awal (roughly translatable, as 'Oh, First Shift Change'), a particularly elaborate and rich kiln workers' song, allows us to do just that. It demonstrates that at least in this instance, work's dangers were an integral part of the singing cultures workers developed. ${ }^{12}$

Ya Badal Awal's short hemistiches and simple, consistent rhyming patterns provide the song with a rhythmic character, evident even in the absence of a clear sense of what its melody may have been. Meanwhile, the images generated by the sections of the song that refer directly to work at the kiln, corroborate descriptions found elsewhere of the limekiln's extreme conditions. ${ }^{13}$ The singing workers reference the desire for the next shift to arrive ('Oh, [the] first shift change/has grown long' (ya badal awal/rah wa-tawal), hinting at the rhythm of labour in the kiln); the kiln's immense heat ('my sweat is like soup': 'araqi maraqi); and wish for death over work ('my death is sweeter': tab al-mawti). They also express a profound disdain for the kiln and its owners, their employers. In a central and violent section, the singing workers wish that the kiln was destroyed, burying underneath its owners and those who built it.

The imagery woven throughout the song likens work in the limekiln to different techniques of cooking meats and describes the sweet smells that emanate from it (but also the 'water made unclean' it produces). The final hemistich of the song beautifully calls this 'stone cuisine' or 'stone cooked fare' (tabih ahjar). Other lines, however, indicate that running parallel to this metaphor, other kinds of 'meat' could be cooked in the kiln's flames. Thus, when 'grilled meat' (lahm amshawa) is first mentioned in the second verse, it is in immediate reference not to the stones being 'fed' to the kiln, but to a description of two men, Hanna and Anțun, who are working inside it. A more direct reference to the dangers of the kiln appears in the first two hemistiches of the verse 
alluded to above, in which the workers wish that the kiln be destroyed, burying its owners with it. Here, the singing worker asks that the kiln (from the top of which flames could rise at times to over 2.5 meters $)^{14}$ be covered, so that it will not devour him (suddu 'ani/la yukalni).

The confusion as to what precisely is being cooked or devoured by the kiln's flames, rock or worker, could hardly have been accidental. Combined with the violent wishes bestowed upon the workers' employers and their own death wishes, it meant that throughout the performance of Ya Badal Awal the dangers faced by kiln workers were never too far removed. The song could then serve, among other things, as an auditory warning of sorts. Alongside the intense heat, the crackling of fire, brushwood and rocks, and in the throes of extremely demanding physical labour, it likely played a role in keeping workers alert.

As is often the case with orally transmitted songs, periodizing $Y a$ Badal Awal proves difficult. Some elements of the song, however, are helpful in approaching a rough estimation of when it may have been sung. Fragments of the song, albeit not ones related to work in the kilns directly, appear already in Gustaf Dalman's I90 I study of Palestinian folklore. ${ }^{15}$ Meanwhile, the patterns of work the song describes (shared ownership, the employment of wage workers in shifts of two and its wood-fuelled operation) seem to pertain to the form of local kiln described by Omar Ahmad Hassan. The products of such kilns, as mentioned above, were gradually, but not entirely, supplanted by larger carbon-fuelled kilns and Portland cement and its products during British rule. Therefore it is likely that the song dates from the first half of the twentieth century.

For the purposes of assessing how the sound of danger differed between sites where building materials were manufactured, a precise periodization is perhaps unnecessary. Descriptions of the sonic environment of the second site of production examined here, the Nesher Cement factory, make one thing clear: it is unlikely that the factory heard much singing. The sound of danger would have to take another form.

\section{Shrieking Machines and Deathly Silence at Nesher Cement}

Not unlike some of the scholarly works mentioned at the beginning of this essay, Hebrew language newspapers in British Mandate 
Palestine seemed to have identified modern urbanism and industry with an almost omnipresent din. For Davar, one of the period's leading dailies, associated with the mainstream of Labour Zionism and its amalgamation of socialism and nationalism, such hubbub was often linked to a positive and specifically modern productivity. Thus, when the newspaper featured a review of Fritz Lang's silent film Metropolis in December I928, the title chosen for it was 'Song of the City' (Shirat ha-Krakh). Despite declaring the medium of the silent film (reino' $a$, literally 'moving sight') the herald of urbanism, it was the sounds, noise, tempo and rhythms of Lang's cinematic city which fascinated the reviewer most. These together became "chords of urbanistic music, a symphony of a metropolis' (aqordim shel musika urbanistit, simphonia shel metropolin). ${ }^{16}$

While the review of Metropolis combined fascination with a certain degree of dread at the noisy future, contemporaries also cast the constant noise of modern industry less ambivalently. This was, for example, the case when the Nesher Cement factory was the focal point of a section of the August I2, I932 children's issue of Davar, dedicated to letters from readers. I I-year-old Yehudit, from the Nesher-Yagur area where the factory was located, described in a letter to the newspaper how the cement factory filled their lives with sound. Even while the neighbourhood is asleep, Yehudit wrote, the factory is always awake. The 'screeching sounds of the machines' (kolot hariqa shel ha-mekhonot), and 'whistles of a thousand kinds' (alfei ofen shorqim), are in her telling, emblems of productivity and progress, the sounds of making 'cement to build the land' (melet le-vinyan ha-aretz) and 'blessed work' (brukha ha- 'avoda). A drawing of the factory, by the ten-year-old Binyamin, also from Nesher-Yagur (Figure I), which the child drew so that 'the readers ... see how great the product of "Nesher" is, and how hard the work,' was chosen by the editors of the paper to accompany Yehudit's letter. ${ }^{17}$

Between the pages of the very same newspaper, the sound of Nesher's factory could, however, also become menacing noise, linked directly to the dangers of work there. This was the case in an article published on 25 July I929, 'In the Vulture's Talons' (be-Tziporne haNesher, nesher being the Hebrew word for vulture, a choice of name which seems unfortunate in itself). Here, 'the constant shrieking of chains and wheels' and 'hysterical-annoying sirens' (a description not too far off from the eleven-year-old Yehudit's 'screeching sounds of 


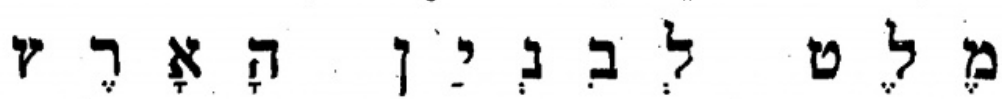

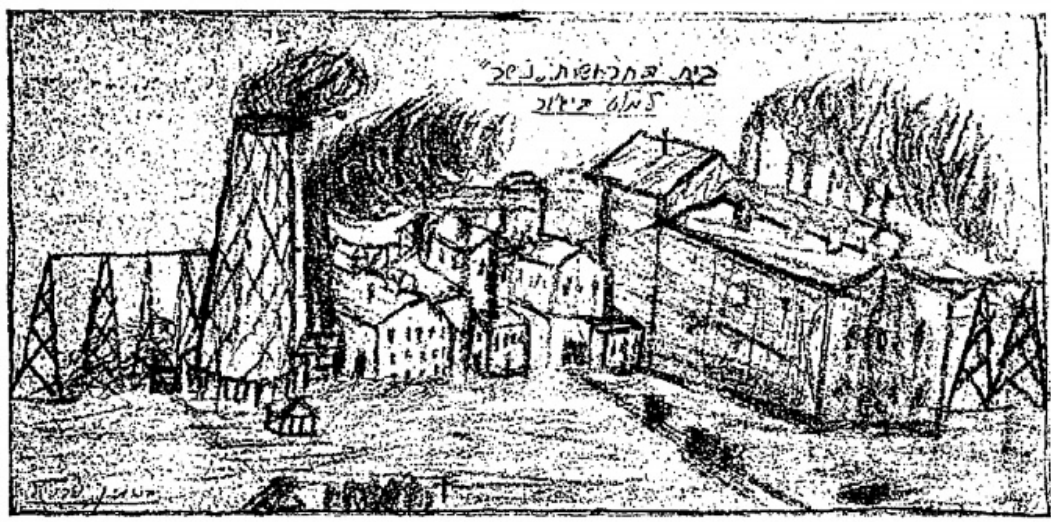

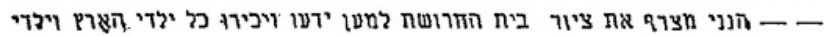

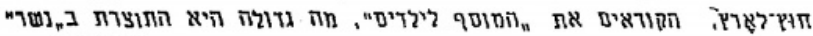
בנימין

וכמה קשה היא העבודה.

בן 10, נשרייגור

Figure I. The 'Nesher' Cement Factory in Yajur, by Binyamin, Io years-old, NesherYagur. Source: 'Melet le-Vinyan ha-Aretz' ['Cement to Build the Land'], Davar (I2 August I932), 9.

the machines' and 'whistles of a thousand kinds') became part of a violent ritual, which although wordless invoked imagery that echoed the Palestinian limekiln song analyzed above. In 'In The Vulture's Talons', the factory, referred to as 'the machine', is described as demanding 'sweat and vitality, brains and blood' (ze 'a u-on, moah u-dam). The din becomes no longer a signifier of productivity, but a warning in and of itself. Dangerous work is made palpable through the description of its sound. Indeed, sound is also what signifies when danger materializes:

And suddenly - silence. The immense machine stops, a howling siren cuts through the air out of turn: D-I-S-A-S-T-E-R! A victim has fallen.

A shudder runs through the backs of the hunched people, for a moment the breath stops, the fist is clenched, and the teeth grind.

Half an hour later the siren sounds again, a cracking of the whip - and they return to the whirlwind, and it is done... R.I.P. ${ }^{18}$ 
Here too, then, danger was performed acoustically. Not by workers' voices, but by the machinery of the factory, orchestrated by the management on the floor. Davar's author used the constant din of production to portray an atmosphere pregnant with danger, finally realized with a sequence of silence and then sound out of place. ${ }^{19}$

\section{Conclusion}

On the outskirts of Palestine's cities, throughout the gradual, incomplete transition from the 'traditional' limekiln to the modern cement factory during the early twentieth century, sound could frame dangerous work for both workers and onlookers. To be sure, the ways in which it did so were different. A Palestinian Arab worker singing Ya Badal Awal while toiling at the kiln, was perhaps no less menaced by the song's words and the prospects of injury than his Jewish peer at the Nesher cement factory was by the spectre of the machine's falling silent and the siren that followed. But there was a qualitative difference in the ability of each to shape the ways in which danger sounded, to grant it presence. Lest we map this sonic difference onto the racialized national gulf that increasingly separated the Arab and Jewish communities during the Mandate, it is instructive to note that the aural warning of an imminent explosion in Palestine's stone quarries, the call 'Barud!' (Arabic for gunpowder) was wholly adopted by Jewish quarry workers. We should also not idealize the sonic agency of the pre-industrial limekiln in contrast to the modern factory. If Ya Badal Awal tells us anything at all about work in the limekilns, it is that hired workers reviled it. Rather than romanticizing one situation over the other, what we can take away from this brief history of the sound of danger is the need to expand the scope of our studies of sound and the sensory. Such studies need to examine new social realms and situations, new geographies and different spaces, as well as to incorporate new sources. Only by doing so will we come closer to grasping the varying ways modernity and urbanization sounded, often at the very same time.

\section{Notes}

I James G. Mansell, The Age of Noise in Britain: Hearing Modernity (Urbana etc, 2016); Aimée Boutin, City of Noise: Sound and Nineteenth-Century 
Paris (Urbana etc, 20I5); Adam Mack, Sensing Chicago: Noisemakers, Strikebreakers, and Muckrakers (Urbana etc, 20I5); Nicolas Kenny, The Feel of the City: Experiences of Urban Transformation (Toronto, 2014). See also Emily Thompson, The Soundscape of Modernity: Architectural Acoustics and the Culture of Listening in America, I900-I933 (Cambridge MA, 2004).

2 Karin Bijsterveld, Mechanical Sound: Technology, Culture, and Public Problems of Noise in the Twentieth Century (Cambridge MA, 2008); Marek Korczynski, Michael Pickering and Emma Robertson, Rhythms of Labour: Music at Work in Britain (New York, 2013).

3 For works that describe various aspects of these changes, see: May Seikaly, Haifa: Transformation of an Arab Society (London, New York, I995); Mark LeVine, Overthrowing Geography: Jaffa, Tel Aviv, the Struggle for Palestine, I880-I948 (Berkeley, 2005); Abigail Jacobson, From Empire to Empire: Jerusalem Between Ottoman and British Rule (Syracuse, 20 I I); Jacob Norris, Land of Progress: Palestine in the Age of Colonial Development, I905-1948 (Oxford, 2013); Sherene Seikaly, Men of Capital: Scarcity and Economy in Mandate Palestine (Stanford, 2016); Fredrik Meiton, Electrical Palestine: Capital and Technology from Empire to Nation (Berkeley, 20I9).

4 'Concrete in Palestine', Cement Age, Io/5 (May I9I0), 37 I. For construction work's share in the economy of Mandate-era Palestine, see Deborah S. Bernstein, Constructing Boundaries: Jewish and Arab Workers in Mandatory Palestine (Albany, 2000), 85-6. For the history of early Zionist attempts to introduce modern cement and concrete as substitutes for local stone construction, see Or Alexandrovich, 'Kurkar, Meleț, 'Aravim, Yehudim: Eikh Bonim 'Ir 'Ivrit' ('Gravel, Cement, Arabs, Jews: How to Build a Hebrew City'), Te'orya u-Vikoret: Bamah Yiśre' elit 36 (Spring 20I0), 6I-87.

5 Moshe Ben-Ner, Menachem Aviram and Menachem Levi (eds), Ha-Melet Ve-Yotzrav: Ha-Ra'ayon u-Mimusho, I923-200I [Cement and its Makers: The Idea and its Fulfillment] (Haifa, 2002), I9-23.

6 Omar Aḥmad Hassan, 'Min al-Ḥiraf al-Sha 'biyya - Șina 'at al-Shid' ('From the Popular [or Folk] Crafts - The Lime Industry'), Al-Turath wa-alMujtama' I7 (I985), I03-2 I.

7 Hassan, 'Min al-Hiraf al-Sha'biyya'. A I937 article from the Hebrew daily Davar, meanwhile, describes an array of Palestinian Arab-owned kilns in the Migdal Tzedek quarry, which employed some Jewish as well as Palestinian Arab labourers and supplied large-scale contracting firms. 
D. Zaslavsky, 'Migdal Tzedek', Davar (6 April i937), 3. Further evidence of various kinds of kilns appears in mandate government records regarding their licensing: Jerusalem District Health Office, 'Lime Kilns' (8 May I946), Israel State Archive (ISA), Mandatory Organizations-Mandate Health-oo Iodze.

8 Ben-Ner et al., Ha-Melet u-Yotzrav, I9-57, 66-9.

9 Hassan, 'Min al-Hiraf al-Sha 'biyya', I Io-2 I; 'Omar Hamdan, al-'Imara al-Sha'biyya fi-Filastin (Popular Architecture in Palestine) (Al-Bireh, I996), I33-37; 'Ali al-Khalili, Aghani al-'Amal wa-l-'Umal fi-Filasțin (Songs of Labor and Laborers in Palestine) (Beirut, I980 [I979]; second edition), 8I-I08; Gustaf H. Dalman, Palästinischer Diwan: als Beitrag Zur Volkskunde Palästinas (Leipzig, I90I), 58-9.

Io al-Khalili, Aghani al-'Amal; Korczynski et al., Rhythms of Labour. A fascinating, if problematic, earlier Palestinian exploration of the embodied nature of song can be found in Yusra Jawhariyyeh 'Arnita, Al-Funun al-Sha 'biyya fi-Filastin (The Popular Arts in Palestine) (Beirut, I968), 43-4.

I I When Korczynski et al., mention dangerous work, they do so specifically in relation to the changing patterns of listening which characterized modern industrial production. These forms of listening were in part related to the need to listen intently to machinery to identify malfunctions and remain alert to possible dangers. These dangers thus played a role in the process of silencing singing at work in Britain which Rhythms of Labour explores. Korczynski et al., Rhythms of Labour, I7I-3.

I2 As seems to be the case with many Palestinian folk songs, neither the long version of the song nor any of its segments appear with distinct titles in the works in which they are featured. Accordingly, and for the sake of convenience, I will be referring to the song by its first hemistich (Ya Badal Awal) throughout this essay. The long version of the song's text, which I rely upon extensively, appears in: Hamdan, al-'Imara al-Sha 'biyya, I335. The particular meaning of the term badal in the context of the limekilns appears in Hassan, 'Min al-Hiraf al-Sha ‘biyya', i I 5.

I3 Hassan, 'Min al-Hiraf al-Sha 'biyya'.

I4 Ibid., I I5.

I5 Dalman, Palästinischer Diwan, 40.

I6 Moshe Harrari, 'Shirat ha-Krakh ("Mețropolis")' ['Song of the City ("Metropolis")'], Davar (6 December I928), 3.

I7 'Melet le-Vinyan ha-Aretz' ['Cement to Build the Land'],' Davar (I2 August I932), 9. An interesting slippage between the Hebrew and 
Arabic names of the locale of the factory occurs in Binyamin's illustration. While the newspaper's editors print both child-authors' locale as NesherYagur, naming both the factory's workers' neighbourhood and the nearby kibbutz, Yagur, in the illustration, Binyamin refers to the factory as 'the "Nesher" cement factory in Yajur', using the name of the nearby Palestinian town later destroyed in 1948 .

I8 Eli 'ezer, 'Be-Tziporne ha-Nesher' ['In the Vulture's Talons'], Davar (25 July I929), 3.

I9 This acoustic motif also appears in descriptions of industrial accidents in other Hebrew newspapers of the period. See for example Yisrael Erlikh, 'Mar'ot' ('Sights'), Ha-Tzofe (2 September 1943), 3.

\section{About the Author}

Nimrod Ben Zeev is a $\mathrm{PhD}$ candidate in the Department of History at the University of Pennsylvania. His research focuses on the intersections between labour, sensory history and political economy in construction work, the construction industry and the built environment in twentieth-century Palestine/Israel. He is particularly interested in the ways in which inequalities, racial hierarchies and masculinity are produced and sustained through labour practices and divisions of risk. In addition to his studies, he is the editorial coordinator of the Social History Workshop, a Hebrew language public history platform intended to make cutting-edge research on Middle East history accessible to a broad audience. E-mail: nimrodb@sas.upenn.edu 